\title{
Drug-Resistance Associated Mutations in Polymerase(P) Gene of Hepatitis B Virus Isolated From Malaysian HBV Carriers
}

\author{
Jeyanthi Suppiah ${ }^{1, *}$; Rozainanee Mohd Zain ${ }^{2}$; Salbiah Haji Nawi ${ }^{2}$; Norazlah Bahari ${ }^{3}$; Zainah \\ Saat ${ }^{1}$ \\ ${ }^{1}$ Virology Unit, Institute for Medical Research, Kuala Lumpur, Malaysia \\ ${ }^{2}$ Microbiology Unit, Hospital Kuala Lumpur, Kuala Lumpur, Malaysia \\ 3 Pathology Unit, Selayang Hospital, Selangor, Malaysia \\ ${ }^{*}$ Corresponding Author: Jeyanthi Suppiah, Virology Unit, Institute for Medical Research, Jln Pahang, 50588, Kuala Lumpur, Malaysia. Tel/Fax: +60-326162674, E-mail: jeyanthi@imr. \\ gov.my
}

Received: July 1, 2013; Revised: October 9, 2013; Accepted: November 1, 2013

\begin{abstract}
Background:Mutations in the polymerase $(\mathrm{P})$ gene of hepatitis B virus are often associated with drug resistance. The pattern of mutations varies geographically, thus giving rise to genotypes diversity.

Objectives: This study was carried out to detect mutations in P gene of hepatitis B virus isolated from Malaysian HBV carriers.

Materials and Methods: A total of 58 sera samples were analyzed by PCR and sequencing, of which the P gene of isolated HBV was successfully amplified and sequenced from 40 samples.

Results: Genotyping of these samples revealed that the predominant genotype was genotype C (22/40, 55.0\%), followed by genotype B $(17 / 40,42.5 \%)$, and only 1 sample showed genotype $\mathrm{D}(2.5 \%)$. A number of significant drug resistant mutations were found in five patients including S202I, N236T, M250L, L180M/V, M204I,A181T,T184G, M250V, and V173L. Of these, L180M/V and M204I were most frequently detected (80\%) and associated with lamivudine in combination with emtricitabine and telbivudine drug resistance. Association with age, sex, and clinical symptoms revealed that these patients were all male, mid to elderly age and almost all hadcirrhotic liver disease.

Conclusions: Detection and surveillance of the significant sites of mutations in HBV is crucial for clinicians to decide on the choice of antiviral treatment and further management of hepatitis B carriers.
\end{abstract}

Keywords: Gene Products, pol; Drug Resistance; Hepatitis B; Mutation; Lamivudine; Genotype

\section{Background}

Infection with Hepatitis B virus (HBV) is a major global health problem affecting over 350 million people in the world (1). HBV is known to cause genomic integration in liver tissue resulting in chromosomal deletions and rearrangements ensuing in metaplasia. Complications arising from chronic infection include liver cirrhosis and hepatocellular carcinoma (HCC). In Malaysia, HBV is known as main etiological agent causing HCC, while HCC is the 7th leading cause of death due to cancers. HBV is transmitted by perinatal, percutaneous, and sexual exposure, as well as by close person-to-person contact presumably by open cuts and sores, especially among children in hyper endemic areas (1).

Due to high mutational rates in the HBV-DNA, the virus could be classified into several genotypes with a standard cut-off of $8 \%$ genomic divergence (2). The most common mutation involved substitution of methionine for valine or isoleucine rtM204V/I (3). Very little studies were car- ried out to detect mutations in HBV isolated from Malaysian population. Study on the mutation in the core and precore promoter region of $\mathrm{HBV}$ in Malaysian carriers has been demonstrated (4). Apart from that, mutation in the immuno-dominant region of pre $S$ and $S$ gene in HBV from infected Malaysian patients has also been studied (5).

\section{Objectives}

However, no findings were reported on the mutations in polymerase $(\mathrm{P})$ gene of $\mathrm{HBV}$ in Malaysia. Therefore, this study focused on sequencing and mutation analysis of $\mathrm{P}$ gene of HBV virus in infected Malaysian patients.

\section{Materials and Methods}

\subsection{Ethics Statement}

This study was ethically approved by Ethics and Medi-

Implication for health policy/practice/research/medical education:

Genomic analysis of HBV P gene isolated from HBV carriers could reveal abundant information including mainly the presence of HBV drug resistant mutants which could lead to prediction of effectiveness of antiviral therapy as well as severity of the disease. Therefore, it is of importance to evaluate antiviral therapy by surveillance of the significant sites of mutations. Early detection of HBV drug resistance is crucial for clinicians to decide on the choice of antiviral treatment and further management of Hepatitis B carriers.

Copyright (C) 2014,BRCGL; Published by Kowsar Corp. This is an open-access article distributed under the terms of the Creative Commons Attribution License, which permits unrestricted use, distribution, and reproduction in any medium, provided the original work is properly cited. 
cal Research Committee, Ministry of Health, Malaysia (Reference number: NMRR-12-311-11789). The ethics committee deemed that patient consent was not required as the samples used were retrospective and confirmed as Hepatitis B carriers positive by Hospital Selayang, Kuala Lumpur, Malaysia.

\subsection{Samples}

A total number of 58 blood serum samples of confirmed Hepatitis B carriers receiving antiviral treatment were obtained in a volume of $2 \mathrm{~mL}$ from Pathology Unit, Hospital Selayang, Kuala Lumpur, Malaysia. Hepatitis B carriers were defined as persons positive for Hepatitis B surface antigen (HBs Ag) for more than six months. The serum samples obtained were retrospective samples collected for a period of two years (2011-2012). Patients were chosen randomly regardless of age, race, sex, and symptoms.

\subsection{Viral-DNA Isolation}

HBV DNA isolation was performed using High Pure Viral Nucleic Acid Extraction Kit (Roche, USA) according to the manufacturer's instructions. The isolation procedure was based on spin-column method. The final elution volume of $50 \mu \mathrm{L}$ containing viral RNA from each sample was stored at $-20^{\circ} \mathrm{C}$ for long-term usage.

\subsection{Polymerase (P) Gene PCR Amplification}

Approximately $2.5 \mathrm{~kb}$ length of polymerase $(\mathrm{P})$ gene of HBV was amplified using 10 sets of published oligonucleotides (6). All oligonucleotides used in this study are listed in Table 1 and Table 2. A fragment of $3.2 \mathrm{~kb}$ was amplified in the first round PCR using sense HB8F and antisense HB6R. A second round of PCR using 9 sets of oligonucleotides (HB1F-HB1R, HB2F-HB2R, HB3F-HB3R, HB4F-HB4R, HB5F-HB5R, HB9F-HB9R, HB10F-HB10R, HB11F-HB11R, HB12F-HB12R) were performed on the $3.2 \mathrm{~kb}$ fragment to produce 9 overlapping fragments that contributed to full length $P$ gene sequence when aligned. All amplification reactions were carried out in a 96-well Thermal Cycler (Bio Rad, USA). The first round of PCR was undertaken for 35 cycles $\left(94{ }^{\circ} \mathrm{C}\right.$ for $1 \mathrm{~min}, 55^{\circ} \mathrm{C}$ for $1 \mathrm{~min}$, and $72{ }^{\circ} \mathrm{C}$ for 1.5 min) followed by an extension reaction at $72{ }^{\circ} \mathrm{C}$ for $5 \mathrm{~min}$. The second round PCR was performed for 30 cycles $\left(94^{\circ} \mathrm{C}\right.$ for $1 \mathrm{~min}, 55{ }^{\circ} \mathrm{C}$ for $1 \mathrm{~min}$, and $72{ }^{\circ} \mathrm{C}$ for $1 \mathrm{~min}$ ) followed by extension at $72{ }^{\circ} \mathrm{C}$ for $5 \mathrm{~min}$. First round PCR reaction was composed of 12.5 uLof 2x MiFi Mix, 1.0 uLof each oligonucleotides (10 uM), $5.5 \mathrm{uL}$ sterile $\mathrm{dH} 2 \mathrm{O}$, and $5 \mathrm{uL}$ of extracted HBV DNA. The second round PCR reaction was composed of the same reagent concentrations for each of 9 sets of oligonucleotides, except that only $2 \mathrm{uL}$ of the first round PCR product was used as template. A synthetic Hepatitis B virus isolate M1 (Gen Bank Accession number: GQ924603) was used as positive control in the initial run to test the primers. A negative control was also included in each run of PCR.

\begin{tabular}{|c|c|c|}
\hline Oligonucleotide Identity & Sequence, $\left(5^{\prime}-3^{\prime}\right)$ & Reference \\
\hline HB8F & TTCACCTCTGCCTAATCATC & Sugauchi et al.(2001)(6) \\
\hline HB6R & AACAGACCAATTTATGCCTA & Sugauchi et al.(2001)(6) \\
\hline & Cr & Defonenco \\
\hline HB1F & AAGCTCTGCTAGATCCCAGAGT & Sugauchi et al.(2001) (7) \\
\hline HB1R & GAAACATAGAGGTGCCTTGAGCAG & Sugauchi et al.(2001)(7) \\
\hline HB2F & TGCTGCTATGCCTCATCTTC & Sugauchi et al. (2001) (7) \\
\hline HB2R & САТАCTTTCCAATCAATAGG & Sugauchi et al. (2001) (7) \\
\hline HB3F & GCCAAGTCTGTACAACATCTTGAG & Sugauchi et al. (2001) (7) \\
\hline HB3R & AGTTGGCGAGAAAGTGAAAGCCTG & Sugauchi et al. (2001) (7) \\
\hline HB4F & CCTATTGATTGGAAAGTATGTCA & Sugauchi et al.(2001) (7) \\
\hline HB4R & CGGGACGTAGACAAAGGACGT & Sugauchi et al. (2001) (7) \\
\hline HB5F & CTCTGCCGATCCATACTGCGGAA & Sugauchi et al. (2001) (7) \\
\hline HB5R & ТТААССТААТСТССТСССССА & Sugauchi et al.(2001) (7) \\
\hline HB9F & TCAGGCAACTATTGTGGTTTCA & Sugauchi et al.(2001)(7) \\
\hline HB9R & GGATAGAACCTAGCAGGCAT & Sugauchi et al. (2001) (7) \\
\hline HB10F & CGCAGAAGATCTCAATCTCGG & Sugauchi et al. (2001) (7) \\
\hline HB10R & GGGTTGAAGTCCCAATCTGGATT & Sugauchi et al. (2001) (7) \\
\hline HB11F & GGGTCACCATATTCTTGGGAA & Sugauchi et al. (2001) (7) \\
\hline HB11R & GAACTGGAGCCACCAGCAGG & Sugauchi et al. (2001) (7) \\
\hline HB12F & GTGGAGCCCTCAGGCTCAGG & Sugauchi et al.(2001) (7) \\
\hline HB12R & CGAGTCTAGACTCTGTGGTA & Sugauchi et al. (2001) (7) \\
\hline
\end{tabular}


Suppiah J et al.

\subsection{Post PCR Purification and Sequencing}

A $10 \mathrm{uL}$ aliquot of each PCR reaction from the second round PCR was analyzed on $2 \%$ agarose by gel electrophoresis and viewed under UV illumination. The agarose was pre-stained with Red Safe Dye (Intron Biotech, Korea) as an alternative to Ethidium Bromide. The corresponding amplicons were extracted from the agarose gel and purified using Gel Extraction Kit (Qiagen, USA) according to the manufacturer's instruction. Final elution contained $35 \mathrm{uL}$ of purified PCR amplicons from which $5 \mathrm{uL}$ was reanalyzed on $2 \%$ agarose gel to confirm that the purification step was performed precisely. All purified PCR amplicons and corresponding sense and antisense oligonucleotides were sent to NHK Bioscience for sequencing.

\subsection{Genotyping Malaysian Hepatitis B Carriers}

Overlapping sense and antisense sequences retrieved because of sequencing were aligned to produce a full length P gene sequence of HBV using CLUSTALW software (http://www.ebi.ac.uk/Tools/msa/clustalw2/). The reference sequence used in the alignment was Hepatitis B virus isolate M1 (Gen Bank Accession number: GQ924603). Subsequently, derived P gene sequences were used to determine genotype of Malaysian Hepatitis B carriers using Genotyper bioinformatics tool in HEPSEQ, International Repository for Hepatitis B Virus Strain Data

(http://www.hpa-bioinformatics.org.uk/HepSEQ-Research/Public/Tool/genotype_tool.php).

\subsection{Analyzing Important Mutations in P Gene}

The P gene full length sequences were analyzed for presence of significant mutations using HEPSEQ polymerase annotator tool. This bioinformatics tool provided the information for mutation and it's indication in a given Hepatitis B sequence.

\section{Results}

\subsection{PCR Amplification of P Gene}

P gene amplification was observed in all 40/58 Hepatitis B serum samples. The remaining 18 sera showed negative amplification. The P region was amplified fragment by fragment with accurate amplicon sizes as shown in Figure 1.

\subsection{P Gene Sequences of Hepatitis B}

Alignment of forward and reverse sequences of each fragment of P gene against the reference strain produced a full length of $2532 \mathrm{bp}$ of $\mathrm{P}$ gene. The sequences were deposited in Gen Bank (Accession numbers: KF053159KF053194).

\subsection{Malaysian Hepatitis B Genotype Analysis}

Based on $P$ gene sequences, genotyping results revealed that, of 40 Hepatitis B patients, 22 belonged to genotype C (55.0\%), 17 were genotype B (42.5\%), and 1 was genotype $\mathrm{D}(2.5 \%)$.

\subsection{Case Report of Mutations in P Gene of Hepa-} titis $B$

Analysis of $\mathrm{P}$ gene sequence revealed that genome of five patients contained mutations that caused drug resistance. The mutations found are as listed in Table 3 and the characteristics of these patients are summarized in Table 4. Based on genome analysis, Patient 155693 possessed mutation A181T, which was responsible to cause resistance to lamivudine. The disease of this patient, a 64-year-old man, was diagnosed as chronic hepatitis B and was on lamivudine treatment from May 2006-February 2007, then restarted from May 2007 onwards. In 2008, adefovir was added as an antiviral therapy. The patient was followed up until November 2012 and HBV DNA was still detected.

Figure 1. Amplification of P Gene Full Sequence by Fragments in Hepatitis B Samples of a Patient

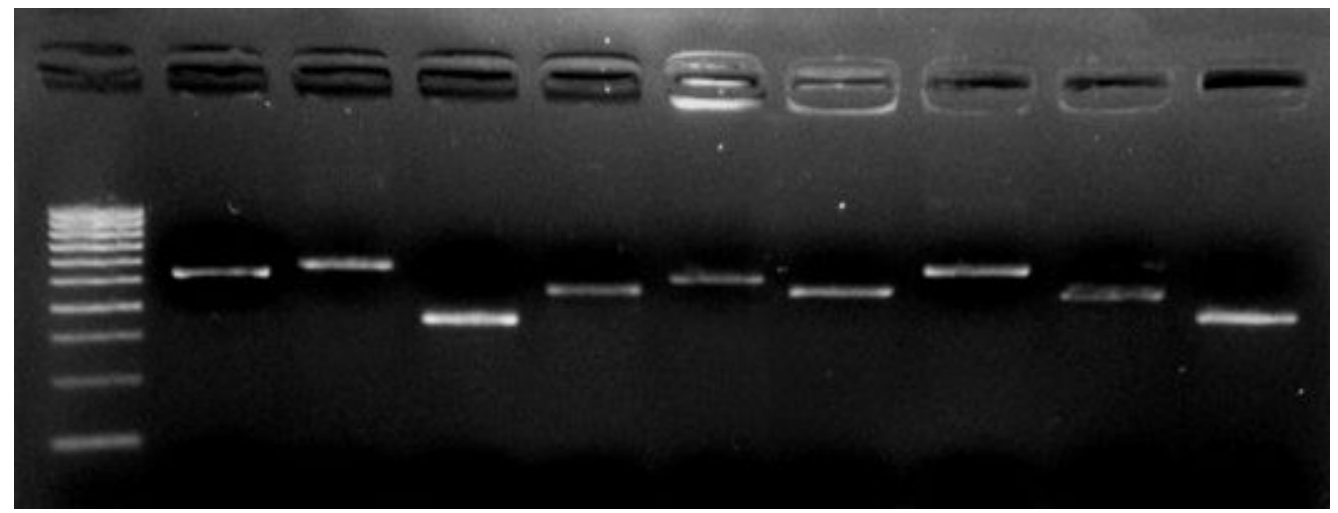

LANE1, 100 bp ladder; LANE 2, HB1(540 bp); LANE 3, HB2(576 bp); LANE 4, HB3(348bp); LANE 5, HB4(465 bp); LANE 6, HB5(50 6 bp); LANE 7, HB9(465bp); LANE 8, HB10(571 bp); LANE 9, HB11(462bp); LANE 10, HB12(382bp); Amplicons shown were related to purified PCR products. 
Suppiah J et al.

\begin{tabular}{lll}
\hline \multicolumn{2}{l}{ Table 3. List of P Gene Mutations Found in Patients in This Study and Association with Drug Resistance } \\
\hline P Gene Mutations & Patient Identification & Association With Drug Resistance \\
\hline S202I & 830757 & Entecavir resistant \\
\hline N236T & 830757 & Adefovir resistant \\
\hline M250L & 830757 & Entecavir resistant \\
\hline L180M/ L180V & $247131,630304,839920$ & Lamivudine, Emtricitabine and Famciclovir resistant \\
\hline M204I & $247131,630304,839920$ & Lamivudine, Emtricitabine and Telbivudine resistant \\
\hline A181T & 155593 & Lamivudine and Adefovir resistant \\
\hline T184G & 247131 & Entecavir resistant \\
\hline M250V & 247131 & Entecavir Resistant \\
V173L & 839920 & Lamivudine, Emtricitabine and Telbivudine resistant \\
\hline
\end{tabular}

\begin{tabular}{|c|c|c|c|c|c|}
\hline Patient ID & Sex & Age & History of Treatment & HBV Viral Load & Clinical Diagnosis \\
\hline 155693 & Male & 64 & $\begin{array}{l}\text {-On Lamivudine since May } 2006 \\
\text {-Jan 2007, No treatment Feb 2007- } \\
\text { May 2007, Adefovir added on Sept } \\
2008 \text { - Nov 2012, Non-compliant } \\
\text { with meds, No follow up since Nov } \\
2012\end{array}$ & $\begin{array}{l}\text { Before treatment: } 5.4 \times 107 \\
\mathrm{iu} / \mathrm{mL} \text {, Last reading in } \mathrm{Apr} \\
2012:<20 \mathrm{iu} / \mathrm{mL}\end{array}$ & $\begin{array}{l}\text { Chronic Hepatitis B, U/S abdo- } \\
\text { men showed fatty liver with } \\
\text { multiple cysts and cholelithia- } \\
\text { sis, No cirrhosis }\end{array}$ \\
\hline 247131 & Male & 48 & $\begin{array}{l}\text {-On tenofovir since Dec 2011,Also } \\
\text { treated with Ciprofloxacin IV } \\
\text { on discharge for Spontaneous } \\
\text { bacterial peritonitis, No history } \\
\text { of treatment failure, No follow up } \\
\text { after discharge (Jan 2012) }\end{array}$ & Not available & $\begin{array}{l}\text {-Decompensated liver cirrhosis, } \\
\text { U/S abdomen showed sple- } \\
\text { nomegaly, gross ascites, and } \\
\text { pleural effusion }\end{array}$ \\
\hline 830757 & Male & 28 & $\begin{array}{l}\text { - Referred from another hospital } \\
\text { for further management of Hep B, } \\
\text {-No information available on the } \\
\text { antiviral treatment, Ptimproved } \\
\text { well, no HBV DNA detected, } \\
\text { biochemical parameters showed } \\
\text { improving trend }\end{array}$ & Not available & $\begin{array}{l}\text {-Possible drug induced hepatitis, } \\
\text { No liver cirrhosis, Present with } \\
\text { jaundice }\end{array}$ \\
\hline 630304 & Male & 46 & $\begin{array}{l}\text {-Initially on Lamivudine since June } \\
\text { 2009, later switched to tenofovir } \\
\text { from July } 2011 \text { till May } 2012 \text { due to } \\
\text { failure of viral suppression }\end{array}$ & $\begin{array}{l}\text { Before treatment: } 7.6 \times 107 \\
\text { iu/mL, Last reading before } \\
\text { switching to tenofovir: } 1.59 \\
\times 107 \mathrm{iu} / \mathrm{mL} \text {, Three months } \\
\text { after receiving tenofovir: } 1.0 \\
\times 103 \mathrm{iu} / \mathrm{mL} \text {, One year after } \\
\text { receiving tenofovir: }<6 \mathrm{iu} / \mathrm{ml}\end{array}$ & $\begin{array}{l}\text { Liver cirrhosis secondary to } \\
\text { chronic Hepatitis B, Pt keep- } \\
\text { ing well and no signs of liver } \\
\text { decompensation after receiving } \\
\text { tenofovir }\end{array}$ \\
\hline 839920 & Male & 76 & $\begin{array}{l}\text {-Started with tenofovir since Nov } \\
\text { 2011, stopped after } 1 \text { month, - Read- } \\
\text { mitted in May 2012, Admitted to } \\
\text { palliative care unit in Feb } 2013\end{array}$ & $\begin{array}{l}\text { Before treatment: } 2.86 \times 105 \\
\text { iu/mL, After treatment: Not } \\
\text { available }\end{array}$ & $\begin{array}{l}\text { Initial OGDS showed mul- } \\
\text { tiple hematin-based ulcers in } \\
\text { stomach and duodenum, U/S } \\
\text { revealed liver cirrhosis with } \\
\text { nodular outline, Diagnosed as } \\
\text { advanced hepatitis B Hepatocel- } \\
\text { lular Carcinoma complicated } \\
\text { with liver cirrhosis, Patient } \\
\text { passed away in Feb } 2013\end{array}$ \\
\hline
\end{tabular}

Patient 247131 was found to have mutations L180M, M204I, T184G, and M250V, which were associated with resistance to lamivudine, entecavir, emitricitabine, famciclovir, and telbivudine. The disease of a 48-year-old male was diagnosed as decompensated liver cirrhosis. The patient was treated with tenofovir since Dec 2011 and no history of treatment failure found. The patient was not followed up thereafter.

Patient 830757 also had multiple mutations in HBV P gene, which were S202I, N236T, and M250L. These mutations were known to cause resistance towards entecavir and adefovir. This patient, a 26-year-old male, initially di- 
agnosed with possible drug induced hepatitis in 2011 by Sultanah Aminah Hospital, was sent to Selayang Hospital for further management of Hepatitis B/C. When patient was readmitted in 2012, no HBV DNA was detected, therefore discharged within three days of admission. No information was available on the antiviral treatment given to this patient.

Analysis of the HBV P gene sequence of patient 630304 showed presence of two significant mutations which were L180M and M204I, indicating possible multi-drug resistance to lamivudine, emtricitabine, famciclovir, and telbivudine. The patient, a 46-year-old man, was presented with liver cirrhosis secondary to chronic HBeAg positive. The patient initially started on lamivudine for a period of two years, then switched to tenofovir mid of 2011 onwards due to failure of viral suppression. It was also stated that no resistant test was available at that time. As of May 2012, HBV DNA was still detected, however the viral load had remarkably descended from approximately 15 , $900,000 \mathrm{IU} / \mathrm{mL}$ (just before switching to tenofovir) to $<$ $6 \mathrm{IU} / \mathrm{mL}$. The patient was reported thereafter to have no more symptoms or signs of liver decompensation.

Based on sequence analysis, patient 839920, a 76-yearold male, showed the presence of L180V, M204I, and V173L mutations in P gene sequence of HBV DNA. These mutations were associated with resistance to lamivudine, emtricitabine, telbivudine, and entecavir.Full sequence amplification failed for this particular patient, therefore only partial sequence was retrieved. Clinical history of the patient revealed liver cirrhosis and ascites. The patient was on tenofovir treatment since 2011 but was noncompliant. Patient's health condition was deteriorating and he passed away in February 2013 due to advanced hepatocellular carcinoma.

\section{Discussion}

The HBV virus is currently genotyped into ten (A-J) genotypes (7). The prevalence of HBV genotypes varies depending on the geographical distribution (4). Genotype A is prevalent in the United States, Northern Europe, Central Africa, and Latin America. Genotype B and C were dominant in the Asian Region, while Genotype D had a worldwide distribution but most prevalent in the Mediterranean and Western Asian countries. The distribution of genotype $\mathrm{E}$ and $\mathrm{F}$ was reported in West Africa and United States respectively, whereas genotype $G$ was only detected in France and United States. The presence of genotype $\mathrm{H}$ was reported in Central America (8). In 2008 a new variant of genotype was added namely genotype I (9), while in 2009, genotype J was isolated from a Japanese patient (10).

In our study, it has been found that genotype C (55.0\%) was dominant but only with a slightly higher prevalence than genotype B (42.5\%). This finding differs from another study (11) that reported $53.4 \%$ of the Malaysian HBV positive was found to be of genotype B, followed by $13.6 \%$ of genotype $C$ and 1.1\% of genotype D and E. In another study conducted in Malaysia population, equal distribution of genotype B and C was found, however the sample size was too small (5). Our study result was comparable with many previous reports on the geographical distribution of HBV genotypes, whereby both genotypes B and C were most prevalent in Asia $(12,13)$. Among our study population, only one patient was found with genotype D. The HBV isolated from this patient contained a 31-nucleotide deletion at the location which was also the beginning of PreS1open reading frame. This deletion has been reported exclusively for in Genotype D of Hepatitis B and non-human primate isolates (14). Based on ethnicity, HBV genotype $C$ was equally distributed among Malay and Chinese patients. However, genotype B was seen more frequently (64.7\%) in Chinese people. Similar finding was reported with frequency of $80 \%$ of genotype B among Malaysian Chinese (15).

The HBV genomic variations in P gene region have clinical importance. The mutations in this region have been reported to have association with drug resistance in patients. For antiviral therapy, five nucleoside/nucleotide analogues (lamivudine, adefovir, entecavir, telbivudine, and tenofovir) are approved at the present by European Association for the Study of Liver. Lamivudine resistance mutants were reported to harbor M240V/I in the YMDD motif of the polymerase gene (16). Adefovir resistance was caused by N236T and /or A181V amino acid substitution (17), whereas entecavir resistance resulted from HBV reverse transcriptase substitutions at positions T184, S202, or M250L which emerge in the presence of lamivudine resistance substitutions M204I/V and L180M (18). Resistance to telbivudine has been associated with M204I mutation (19). Emtricitabine resistance was often accompanied with lamuvudine resistance because of L180M, V173L, and M204I mutations (20).

The results of this study have demonstrated drug resistant HBV mutations in five patients. All five patients were male with the age ranging from 26-76 years. Based on the genome analysis, HBV isolated from four out of five patients $(80 \%)$ contained mutations associated with lamivudine resistance in combination with either of emtricitabine, telbivudine, or adefovir. Another study has also reported high frequency of lamivudine resistance in up to $70 \%$ of $\mathrm{HBV}$ patients who were treated 5 years with lamivudine, $29 \%$ after 5 years with adefovir, 20\% after 2 years with telbivudine, and $1 \%$ after 5 years with entecavir (21). The mutations found in the four patients were $\mathrm{L} 180 \mathrm{M} / \mathrm{V}$, M204I, A181T, and V173L.Among these, L180M/V and M204I were frequently observed. Some study reported that in most cases, the M204V/I mutation was not present alone but linked with a leucine to methionine exchange at position 180 (L180M) (22). Similarly, three out of five patients contained both M204I and L180M/V. Mutations associated with entecavir and adefovir resistance were the next frequently observed in two patients each (40\%).

It was observed that the four HBV isolates (247131, 
630304, 839920, and 155593) with lamivudine resistant mutations were all from patients who were on lamivudine treatment at some points. Interestingly, two patients have completely recovered after switching of antiviral therapy from lamivudine to tenofovir. This indicates the efficacy of tenofovir as treatment for HBV patients. This finding is supported by Fung et al.(2012)(23) stating that tenofovir has shown high barrier to resistance, produced high rates of viral suppression, and showed no evidence of resistance through six years for previously untreated chronic hepatitis B patients. Similar finding was also demonstrated whereby regression of cirrhosis during treatment was observed with tenofovir in chronic hepatitis B patients in a five-year follow-up (24). The remaining two patients did not recover, as one patient was still on lamivudine treatment and the other died recently. The dead patient was reported to have been on tenofovir treatment since 2011, however was non-compliant, which could be the possible cause of treatment failure. Two patients had HBV mutant associated with adefovir resistance (830757 and 155593), in one patient of which adefovir treatment as second-line treatment with lamivudine was confirmed. Genomic analysis revealed that HBV from this patient also had lamivudine resistant mutation. This finding supports earlier studies (25) that demonstrated adefovir resistance occurred more frequently in secondline treatment of lamivudine-resistant patients than in naive patients. Therefore administration of adefovir in patients with history of lamivudine resistance should be abandoned. The other patient's treatment history was unclear, but there was a possibility that this patient has also received adefovir treatment.

Analysis on symptoms of five patients with HBV P gene mutants revealed thatthe disease of three patients were diagnosed as liver cirrhosis and the remaining two as chronic hepatitis B and drug induced hepatitis, respectively. All three patients with liver cirrhosis contained HBV mutant L180M in combination with M204I. However, to conclude if there is any association of hepatitis B disease symptoms with the presence of drug resistant mutants, larger sample sizes need to be used. Larger sample size would be an advantage for this study. However, the findings in this study has potential clinical impact, as none of the drug resistance mutations were reported in Malaysian patients neither have they been published.

In conclusion, genomic analysis of HBV P gene isolated from HBV carriers could reveal abundant information including mainly the presence of HBV drug resistant mutants which could lead to prediction of effectiveness of antiviral therapy as well as severity of the disease. Therefore, it is of importance to evaluate antiviral therapy by surveillance of the significant sites of mutations. Early detection of HBV drug resistance is crucial for clinicians to decide on the choice of antiviral treatment and further management of Hepatitis B carriers.

\section{Acknowledgements}

The authors would like to thank the Director General of Health Malaysia for his permission to publish this paper. We also would like to extend our gratitude to Dr. Shahnaz Murad, The Director of Institute for Medical Research Malaysia for her support. This project was funded by Ministry of Health, Malaysia [JPP-IMR: 12-006, NMRR-12-311-11789 and Akaun Amanah 16833].We also acknowledge the use of the Hep SEQ-Hepatitis B resource (www.hpeseqresearch.org). Gnaneshan S., Ijaz S., Moran J., Ramsay M. and Green J. (2007) Hep SEQ: International Public Health Repository for Hepatitis B. Nucleic Acids Res., 35 (Database Issue): D367-70.

\section{Authors' Contribution}

Jeyanthi Suppiah was involved in the entire study, conducting experiments, analysis and interpretation of data and drafting the manuscript. Rozainanee Mohd Zain delivered intellectual content to the study. Salbiah Haji Nawi and Norazlah Bahari contributed to sample provision and clinical knowledge. Zainah Saat contributed to intellectual content, study design and concept and revision of the manuscript.

\section{Financial Disclosure}

Authors have no financial interests related to the material in the manuscript.

\section{Funding/Support}

This study was funded by Ministry of Health, Malaysia [JPP-IMR: 12-006, NMRR-12-311-11789 and Akaun Amanah 16833].

\section{References}

1. Mast EE, Margolis HS, Fiore AE, Brink EW, Goldstein ST, Wang $\mathrm{SA}$, et al. A comprehensive immunization strategy to eliminate transmission of hepatitis B virus infection in the United States. MMWR. 2005;54(16):1-32.

2. Bowyer SM, Sim JG. Relationships within and between genotypes of hepatitis B virus at points across the genome: footprints of recombination in certain isolates. J Gen Virol. 2000;81(Pt 2):379-92.

3. Allen MI, Deslauriers M, Andrews CW, Tipples GA, Walters KA, Tyrrell DL, et al. Identification and characterization of mutations in hepatitis B virus resistant to lamivudine. Lamivudine Clinical Investigation Group. Hepatology. 1998;27(6):1670-7.

4. Har Ton So, Meng Tan Tsui, Siang Khoo Boo, Zawawi Mazlam, Thanaletchimy Nagalingam. Hepatitis B Virus Genotypes and Pre-core/Core Promoter Mutations in Malaysian Carriers. Malays J Biochem Mol Biol. 2005;12:14-20.

5. Ong HT, Duraisamy G, Kee Peng N, Wen Siang T, Seow HF. Genotyping of hepatitis B virus in Malaysia based on the nucleotide sequence of preS and S genes. Microbes Infect. 2005;7(3):494-500.

6. Sugauchi F, Mizokami M, Orito E, Ohno T, Kato H, Suzuki S, et al. A novel variant genotype $C$ of hepatitis $B$ virus identified in isolates from Australian Aborigines: complete genome sequence and phylogenetic relatedness. J Gen Virol. 2001;82(Pt 4):883-92.

7. Brunjes PC. A comparative study of prenatal development in the olfactory bulb, neocortex and hippocampal region of the pre- 
cocial mouse Acomys cahirinus and rat. Brain Res Dev Brain Res. 1989;49(1):7-25.

8. Arauz-Ruiz P, Norder H, Robertson BH, Magnius LO. Genotype $\mathrm{H}$ a new Amerindian genotype of hepatitis B virus revealed in Central America. J Gen Virol. 2002;83(Pt 8):2059-73.

9. Tran TT, Trinh TN, Abe K. New complex recombinant genotype of hepatitis B virus identified in Vietnam. J Virol. 2008;82(11):565763.

10. Tatematsu K, Tanaka Y, Kurbanov F, Sugauchi F, Mano S, Maeshiro $T$, et al. A genetic variant of hepatitis $B$ virus divergent from known human and ape genotypes isolated from a Japanese patient and provisionally assigned to new genotype J.J Virol. 2009;83(20):10538-47.

11. Lim CK, Tan JT, Khoo JB, Ravichandran A, Low HM, Chan YC, et al. Correlations of HBV genotypes, mutations affecting HBeAg expression and HBeAg/ anti-HBe status in HBV carriers. Int J Med Sci. 2006;3(1):14-20.

12. Lindh M, Andersson AS, Gusdal A. Genotypes, nt 1858 variants, and geographic origin of hepatitis B virus--large-scale analysis using a new genotyping method. Infect Dis. 1997;175(6):1285-93.

13. Magnius LO, Norder H. Subtypes, genotypes and molecular epidemiology of the hepatitis B virus as reflected by sequence variability of the S-gene. Intervirology. 1995;38(1-2):24-34.

14. Schaefer S. Hepatitis B virus: significance of genotypes. J Viral Hepat. 2005;12(2):111-24.

15. Meldal BH, Bon AH, Prati D, Ayob Y, Allain JP. Diversity of hepatitis $B$ virus infecting Malaysian candidate blood donors is driven by viral and host factors. J Viral Hepat. 2011;18(2):91-101.

16. Betka J, Valvoda M, Hruby J, Skrivan J. [The surgical approach and results of implantation of the Czech cochlear neuroprosthesis]. Cas Lek Cesk. 1989;128(11):339-41.

17. Schildgen O, Sirma H, Funk A, Olotu C, Wend UC, Hartmann H, et al. Variant of hepatitis B virus with primary resistance to adefovir. N Engl J Med. 2006;354(17):1807-12.

18. Tenney DJ, Rose RE, Baldick CJ, Pokornowski KA, Eggers BJ, Fang J, et al. Long-term monitoring shows hepatitis B virus resistance to entecavir in nucleoside-naive patients is rare through 5 years of therapy. Hepatology. 2009;49(5):1503-14.

19. Lai CL, Gane E, Liaw YF, Hsu CW, Thongsawat S, Wang Y, et al. Telbivudine versus lamivudine in patients with chronic hepatitis B. $N$ Engl J Med. 2007;357(25):2576-88.

20. Fujisaki S, Yokomaku Y, Shiino T, Koibuchi T, Hattori J, Ibe S, et al Outbreak of infections by hepatitis B virus genotype A and transmission of genetic drug resistance in patients coinfected with HIV-1 in Japan. J Clin Microbiol. 2011;49(3):1017-24.

21. Strasfeld L, Chou S. Antiviral drug resistance: mechanisms and clinical implications. Infect Dis Clin North Am. 2010;24(2):413-37.

22. Tacke F, Shirvani-Dastgerdi E. Impact of Drug-Resistance Polymerase Mutations on the Replication of HBeAg-Positive and HBeAg-Negative Hepatitis B Virus Strains in Vitro. Hepat Mon. 2012;12(6):357-60.

23. Fung S, Kwan P, Fabri MJ, Horban A, Petr Husa P, Hann HH, et al Efficacy and safety of Tenofovir DF (TDF) in chronic hepatitis B virus infected patients with documented lamivudine resistance (LAM-R): Highlights from American Association for the Study of Liver Diseases; 2012

24. Marcellin P, Gane E, Buti M, Afdhal N, Sievert W, Jacobson IM, et al. Regression of cirrhosis during treatment with tenofovir disoproxil fumarate for chronic hepatitis B: a 5-year open-label follow-up study. Lancet. 2013;381(9865):468-75.

25. Lee YS, Suh DJ, Lim YS, Jung SW, Kim KM, Lee HC, et al. Increased risk of adefovir resistance in patients with lamivudine-resistant chronic hepatitis B after 48 weeks of adefovir dipivoxil monotherapy. Hepatology. 2006;43(6):1385-91. 